
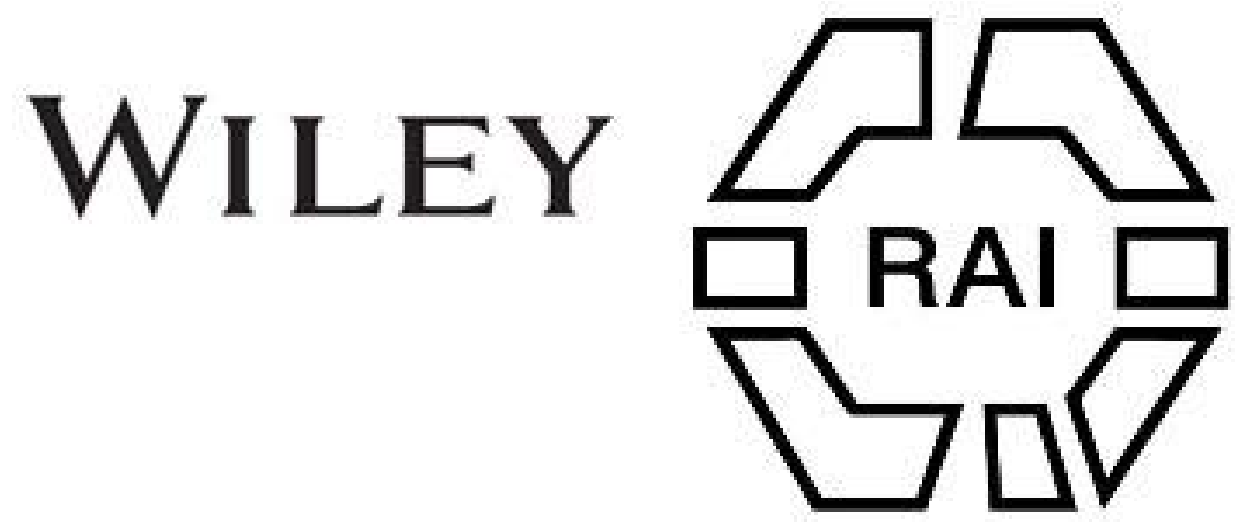

\title{
25. Thin Arrowheads.
}

\section{Author(s): W. Allen Sturge}

Source: Man, Vol. 7 (1907), p. 37

Published by: Royal Anthropological Institute of Great Britain and Ireland

Stable URL: http://www.jstor.org/stable/2787363

Accessed: 26-06-2016 20:21 UTC

Your use of the JSTOR archive indicates your acceptance of the Terms \& Conditions of Use, available at

http://about.jstor.org/terms

JSTOR is a not-for-profit service that helps scholars, researchers, and students discover, use, and build upon a wide range of content in a trusted digital archive. We use information technology and tools to increase productivity and facilitate new forms of scholarship. For more information about JSTOR, please contact support@jstor.org.

Wiley, Royal Anthropological Institute of Great Britain and Ireland are collaborating with JSTOR to digitize, preserve and extend access to Man 
with a honp-iron adze, and it must have been a laborious task; the trunk was from 15 to 18 inches in diameter. I presume the same course was followed when stone or shell adzes were in use and, as I am not aware that any one has ever described or illustrated the method of procedure, I append a sketch showing the method of felling.

All I was able to procure in the way of language was the following:-

Numerals.-1, tasi ; 2, gua ; 3 , tolu ; 4, va ; 5 , lima ; 6 , ono ; 7, vitu ; 8, walu ; 9, sivo; 10, katoa. Eye, mata; ship, vaka; mouth, gutu ; tooth, niho ; nose, isu ; ear, tagina ; hand, tonu ; foot, tapuna ; wood, gau.

Even these few words will serve to show the Polynesian origin of the Rennell islanders.

C. M. WOODFORD.

\section{Archæology.}

Sturge.

Thin Arrowheads. By $W$. Allen Sturge.

In connection with the arrowhead found at Cannington Park Camp, near 24 Bridgwater, Somerset, and figured in MAx, 1906, 96, it may be of interest to record the fact that in my collection is an arrowhead which in shape, size, and thinness corresponds almost exactly with this piece. The type with the ogee outline is not common, but $I$ have specimens of this very special type from Gloucestc:shire, Derbyshire, and the Yorkshire Wolds. The arrowhead I am comparing with that recorded by $\mathrm{Mr}$. St. George Gray is one of five which were found in two of the stone cists in Ringham Low, Derbyshire, explored by the late Mr. Thomas Bateman in 1885, and recorded in Ten Years' Diggings, p. 95.

Another of these five arrowheads is of the same shape but considerably liurger, being perhaps the finest specimen of the variety ever found. It measures $2 \frac{3}{8}$ inches in length by 1 inch in breadth at its widest part. It is extremely thin and weighs only 42 grains.

'Two others of the five arrowheads are equally large and equally thin, and of the finest possible workmanship; but they are more definitely kite-shaped and do not present the ogee outline. The fifth is smaller and resembles the two first described, except that the outline going up to the point is straight instead of incurved.

Mr. Gray may, I think, take it as certain that all arrowheads of this particular variety were pointed at the lower end. There are certain types with the ogee outline which have rounded bases, but none of these types are quite comparable with the particular typ in questis.

W. ALLEN STURGE.

Wales: Archæology.
Notes on some Rude

Iewis.

By A. L. Lewis, F.C.A.

About six miles west from Cardiff, on a farm called Tinkinswood, which is in a lane between St. Nicholas village and Duffryn House, there have been several cromlechs or dolmens. The largest of these is in a little wood near the farmhouse, and is the only one of which any particular notice seems to have been taken. It has been described under the name of the St. Nicholas eromlech by the Rev. E. L. Barnwell in the Journal of the Royal Archæological Institute about twenty years ago, and in Lewis's Topographical Dictionary, where it is stated to be composed of "large flat " stones nearly 6 feet in height, enclosing an area of 17 feet in length by 13 feet in " breadth, upon which rests a table 24 feet long and varying in breadth from 17 feet " to 10 feet." Mr. Barnwell said the chamber "is 19 feet long and hardly 11 feet " broad, but, as upon one side of the chamber all the stones have been.removed, it " is not easy to decide where the line should be drawn." Since his visit to it the chamber has been partly filled with earth, which makes it still more difficult to

$$
\left[\begin{array}{ll}
37 &
\end{array}\right.
$$

